\title{
The Qur'an Based Character Education in Schools
}

\author{
A May ${ }^{1}$ \\ UIN Sultan Syarif Kasim Riau, Jl. HR. Soebrantas Suka Gg. Sabar Panam Pekanbaru ${ }^{1}$ \\ \{asmalmay.uinsuska@gmail.com ${ }^{1}$ \}
}

\begin{abstract}
The Qur'ān was revealed to Muhammad in order to elevate humanity from the valley of darkness to brightness. History proves that the jahiliyyah society which has no civilization and the direction and purpose of life was successfully brought by Muhammad to a new, more civilized life, under the light of faith and respects for human dignity. Character education will give color to the nation's character education. Therefore, education is a transformation towards the best educational outputs. All of us, as the children of the nation, is the result of education through informal, formal and non-formal educations which are the three types of education recognized in Indonesia. Our education is education that comes from heaven and is applied by looking at the reality of the earth. The national character of the Qur'an is born from education with the Qur'an characters as well. Therefore, the state must provide a wider space for Islamic religious education in national laws and curricula.
\end{abstract}

Keywords: Qur'ani, Nation, Character, Education

\section{Introduction}

The Qur'an, which was revealed in within twenty-three years both in Mecca or Medina, is the main source of Islamic laws and the first reference for curing all the problems of human life. The Qur'an does not only explain the problems of hablum minnaallah, but it also discusses the relationship between human beings (hablum minnanas). The Qur'an is the words of God revealed to the Prophet Muhammad as a guide for human beings in life in order to obtain happiness in the world and in the hereafter. The concepts brought by the Qur'an are always relevant in all conditions, times and circumstances for it is guidance for mankind (hudallinass).

Islam is a religion that highly exalts, respects and values morals. That is why the main purpose of the Prophet Muhammad being sent to this world is to improve good morals and to erase ignorance as stated in the hadith: "I am not sent but to improve morals."

The principle of morality in Islam lies in the Qur'an. Faith is the foundation of Islamic morality by which a Muslim has an internal power to become a believer. Abu Hurairah narrated a hadith from Rasulullah Saw: "the most perfect believer is the best, and we are the best with his wife" [1].

Education has a very big role in shaping the personality of every human being. Education is a process of developing students' potential to become perfect individuals. One of the indicators is that every student possesses the morality of mercy. As Ki Hajar Dewantara said, there are three 
educational institutions that have a role in developing this potential, i.e. formal, informal and nonformal educations, each of which is represented respectively by a school, family, and environment or community. Thus, school as a formal educational institution is also responsible for educating each student's morals [2]. This is why when negative behaviors arise (mazmumah morals) in the midst of society, the education sector is the one that should be blamed.

In the Law of National Education System, education is a conscious and planned effort to create an atmosphere of the learning process so that students actively develop their potential to have spiritual strength, self-control, personality, intelligence, noble character, and the skills that they themselves, the community, and the nation need. Education is a process and a system that leads to the achievement of certain qualities that are considered and believed to be the most ideal ones. The goal of education in general, and specifically in Islam, is not just to transfer the culture or knowledge (transfer of knowledge) but also the values of Islamic teachings (transfer of values) [3].

Education is one of the means to shape human personality for the purpose of education is to humanize humans. In other words, humans are the caliphs on this earth who have the responsibility to prosper the earth and become the best. As Allah said in the Qur'an.

And when your Rabb said to the angels: "Indeed, I created the Caliph on the face of the earth, the angels also said: Did you create people who do mischief on the earth and also shed blood? While we always glorify and purify You, Allah said: Verily I am All-Knowing while you do not know".QS: al-Baqarah(2): 30.

Based on the explanation above, this paper seeks to examine what the Qur'an based character means and how it can be implemented in schools. This author in this paper discusses some important issues regarding the normative basis of character education as exemplified in the Qur'an and the hadiths.

\section{Method}

This study is qualitative research and seeks to describe and explain the improvement of students' characters through The Qur'an based education. The data was obtained through a library research method for which the author searched, collected, read, and analyzed books relevant to the research problem. The data was processed to the author's best capability. Since this research is a qualitative one, this paper aims to understand a phenomenon in the social context by prioritizing the process of deep communication interaction between the researcher and the phenomenon being studied.

\section{Result and Discussion}

\section{Akhlaq In Islam}

The word Islam originated from Islam, which means surrender to the savior, i.e. Allah Swt. Islam also means salâm which means salvation. Allah's salvation for Muslims is not only in the world but also in the eternal life. Islam is not just to surrender and submission, but it also has consequences that must be carried out by its adherents [4] or servants in the form of worships in their lives. 
The word morals is a plural form of the word khuluq, which refers to behaviors, temperaments, and characters. According to the term, a moral is the power of the soul that encourages actions easily and spontaneously without thinking and pondering again [1]. Etymologically, the word morals derived from the word khalaqa which originally came from khuluqun, which means temperaments, characters, and customs. In addition, morals also come from the word khaqun, which means an event, artificial and created [1]. Thus, morals etymologically mean temperaments, customs, characters, or a system of behaviors.

Morals in the sense of behaviors are driven by a conscious desire to do a good deed. Morals are also a plural form of khuluk, derived from Arabic which means temperaments, behaviors, or characters. The word morality is interpreted as a behavior that is done repeatedly rather than just doing a good deed at one time [1].

In the Qur'an,khuluq is mentioned twice, i.e. in surah al-Qalam verse 4, "And verily you are of great virtue", and surah asy-Syu' ara verse 137, "(Our religion) this is nothing but the customs of the ancients."

The term morality also contains ethical and moral meanings [5]. The difference between morals and ethics is especially related to their sources. Morals come from khaliq (Allah Swt), the Sunnah of the Prophet Muhammad, and the human ijtihad. Whereas ethics and morals come only from human beings. Therefore the use of the term "ethics and morals" which contains the notion of "morals" needs to be added with the word "Islam", i.e. Islamic ethics or Islamic morals.

Morality is a condition, nature, and attitude that is embedded and inherent in a person's soul or tabi'at, and is becoming a personality, from which various actions are born easily without going through a process of thought, consideration, and research

\section{The Aim of the Qur'an is to Educate Morals}

The purpose of moral education according to the Qur'ani the realization of the human spirits accompanied by an understanding of the good and the bad moral education reflected ineffective behaviors in an integrated manner. Human beings who own moral perfection are described in the Qur'an as the ones who follow the examples of the Prophet Muhammad the result of which safety in the world and the hereafter will be granted. The Qur'an stated that moral education includes, among many others, morals towards Allah Swt. and His Messenger, human beings, oneself, families, society, and nature.

Islamic education involves the aspects of the body, reason, creed, emotions, aesthetics, and social. Therefore, Islamic education must be aimed and directed at the development of these aspects for the best interests of human life. In other words, Islamic education wants to shape people who are aware of and carry out the tasks of the caliphate as stated in the Qur'an and enrich themselves with the treasury of knowledge. Islamic education is very much different from a secular Western one. It is not only based on the results of human thoughts in achieving general benefits and universal humanism, rather on Islamic thoughts as taken from the Qur'an and the Hadith. Al-Qabisi suggested that Islamic education aims to prepare students to become Muslims who can adjust their lives according to Islamic teachings. The students are expected to be able to have the knowledge and practice the teachings of Islam because life in this world is nothing but a bridge to life in the hereafter wherein they will be held accountable.

Moral education is a basic part of Islamic religious education because religion is in fact about morals. The presence of the Prophet Muhammad on the earth was in the context of completing 
human morals. As we know, before the coming Islamgirls were killed alive, tribal fanaticism was common, and ignorance was preserved. When human beings have morality or characteristics in accordance with the Qur'an, the evil in their hearts will parish. The key to spread the Qur'an is to inculcate human morality.

Human beings are the noblest and honorable creatures among Allah's creations. Because of this, human beings are appointed to become caliphs (leaders) on earth. The existence of humans as caliphs is the purpose of human beings created on earth. The task or function of human beings as the caliphs is a mandate from God in which they are given extensive rights and authority to regulate nature the benefits of the people. Basically, nature does not need human beings, but human beings need nature. Therefore, human beings must be wise in utilizing nature. They should not just to take advantage but should be able to maintain and take care of nature well.

Natural resources that exist today are not only limited to unilateral use for human beings. What happened is that human beings do not care enough about nature. For example, forests are cut down without reforestation; fish bombing is increasingly carried out. This is why nature is "angry" with themes shown in disasters. Allah SWT. forbids human beings to exploit nature excessively and $\mathrm{He}$ asserted that the occurrence of damage on earth is due to human beings. Therefore, human beings must be aware of God's words by preserving nature.

Every human needs and work should be intended to serve Allah Swt. in order to be counted as worship. The presence of Allah Swt. in every step and action of human beings will ensure that human beings will always try to please their Master as best as possible.

Thus, worship here does not refer merely to mahdah worship but to all our activities from waking up until we fall asleep. These activities should be put within the framework of worship in order to get closer to Allah SWT. This is a reflection that should be in the minds of all mankind, namely positioning Allah Swt as God and humans as His servants. In other words, Allah Swt should be present in all our activities.

\section{Practicing Akhlaq through the Qur'an}

One way to practice the Qur'an characterizes through education. As an academic person, the obligation of students is to practice what is ordered by the Qur'an, so that the characters in education can be achieved. Fostering the characters of the nation in building behaviors and ethics is a very good development and is basic coaching for all students in the school environment. The coaching aims to practice the actions, speech, and thoughts so that the students will always do good especially to themselves, other students, and teachers in school. Similarly, Heri Gunawan [6] revealed that character education is indeed aimed at forming a strong, competitive, and noble nation imbued with faith and devotion to Allah SWT. based on Pancasila. In Islam, the character has an important position and is also given a vital function in guiding a life.

In line with the purpose of education, morals and characters will produce positive activities and attitudes. Therefore, the efforts to re-instill values in the Qur'an and the Hadith become very important. One way to have noble morals as exemplified by the Prophet is by mirroring the personalities of the Prophet because he has the qualities that are praiseworthy and become a guide for his people. Indeed, the Prophet's morals are akhlaq Qur'an. It is undeniable that with noble characters, a firm faith, and excellent qualities, he changed the civilization of the ignorant Arabs at 
that time. One example was that during the time many Jews converted to Islam because they noticed the Prophet's noble behaviors.

Moral or character education can be integrated into learning in each subject. Learning materials related to norms or values in each subject need to be developed, explicit, and contextualized into daily life. In the learning process in the classroom, educators must prepare learning tools such as syllabus, and lesson plans (RPP). This is the first step in planning a character education strategy which is then implemented into learning. It does not only focus on specific subjects but can also be applied in additional subjects, such as extracurricular activities, one of which is tahfidzul alQur'an.

Education is a process towards continuous improvement in terms of goodness, including character education which currently becomes a public conversation, especially among the observers of education. Character education becomes very important because the community still feels that the general education institutions up to now still prioritize children's cognitive over affective and psychomotor capacities.

There are supporting and inhibiting factors as well as solutions that institutions or schools have in applying character education. The supporting factors are the collaboration between educators and teachers in a cohesive manner. The inhibiting factors are the students' background on the nature of the characters of students who are difficult to socialize, and the teacher's lack of patience in conditioning students when implementing character education in learning activities in the classrooms. The solutions for these problems are, first, having regular meetings every semester and giving advice to the students who are difficult to manage. Second, educators or teachers who are generally young and fresh graduates should be trained. Students who still enjoy playing, their concentration on learning should be upgraded. Third, parents and families or communities should become a good example of the formation of students' characters.

Indonesia is explicitly stated as neither a religious state nor a secular State, rather it is the state of Pancasila. Bahtiar Effendi mentioned that a Pancasila State means that Indonesia is taking the middle path between the religious and the secular. The first precept formulation of Pancasila and Article 29 of 1945 Constitution Paragraph (1) gives the characteristic of the State of Indonesia, being not a secular state that separates religion and the state, and not a state of religion based on a particular religion.

\section{Conclusion}

The Qur'ani nation's character was born from education with the Qur'ani character as well. Therefore, the state must provide a greater room for Islamic religious education in national laws and curriculum. Because it has become a fact that Muslim students in Indonesia forge more education in public education than religious ones like Islamic boarding school or madrasa. When students are imbued with morality and good characteristics in accordance with the Qur'an, the evil qualities in their hearts will parish.

Islamic education involves the aspects of the body, reason, creed, emotions, aesthetics, and social. Therefore, Islamic education must be aimed and directed at the development of these aspects for the best interests of human life. In other words, Islamic education wants to shape people who are aware of and carry out the tasks of the caliphate as stated in the Qur'an and enrich 
themselves with the treasury of knowledge. Character education will give color to the nation's character education.

Therefore, education is a transformation towards the best educational outputs. All of us, as the children of the nation, is the result of education through informal, formal and non-formal educations which are the three types of education recognized in Indonesia. Our education is education that comes from heaven and is applied by looking at the reality of the earth. The national character of the Qur'an is born from education with the Qur'an characters as well. Therefore, the state must provide a wider space for Islamic religious education in national laws and curricula.

\section{Reference}

[1] Mukina'ah, Materi Pendidikan Agama Islam untuk Perguruan Tinggi Umum. Yogyakarta: Ar-Ruz Media, 2011.

[2] S. Iskandar, "Studi AlQuran Dan Integrasi Keilmuan: Studi Kasus UIN Sunan Gunung Djati Bandung," Wawasan J. Ilm. Agama dan Sos. Budaya, vol. 1, no. 1, pp. 86-93, 2016.

[3] Rodiah, Studi Qur'an; Metode dan Konsep. Yogyakarta: eLSAQ Press, 2010.

[4] I. Ad-Din, Dalilal-FalihinLi at-thuruqi Riyad as-Sholihin. Kairo: Dar al-Hadist, 1998.

[5] Muhaimin, Wacana Pengembangan Pendidikan Islam. Yogyakarta: Pustaka Pelajar, 2004.

[6] H. Gunawan, Pendikan Karakter Konsep dan Implementasi. Bandung: Alfabeta, 2012. 